\title{
流動層中でのニッケルのホウ化処理
}

\author{
上田順弘*，曾根 匠*，水越朋之*，池永 明**，川本 信**
}

\section{Boriding of Nickel in Fluidized Bed}

\author{
Nobuhiro UEDA*, Takumi SONE*, Tomoyuki MIZUKOSHI*, \\ Akira IKENAGA* and Makoto KAWAMOTO*
}

\begin{abstract}
Boriding is useful in surface hardening nickel $(\mathrm{Ni})$ in many surface treatments. Although Ni boronized by powder-pack boriding with amorphous boron and by gas boriding with $\mathrm{BCl}_{3}$ has been reported, few reports cover boriding in a fluidized bed. We analyzed the treated layer using X-ray diffraction (XRD), glancing incidence X-ray diffraction, glow discharge emission spectrometry (GDS), and electron probe microanalyzer (EPMA). High-temperature microhardness and friction and wear characteristics of boronized Ni were studied, with the following results :

(1) Boriding $\mathrm{Ni}$ at a high temperature over a long time in a fluidized bed showed flaking of the treated layer due to $\mathrm{Ni}$ siliconization.

(2) The Knoop hardness was $1300 \mathrm{HK}$ for the sample boronized $7.2 \mathrm{ks}$ at $1073 \mathrm{~K}$. The boride layer was about 25 $\mu \mathrm{m}$ thick and consisted mainly of $\mathrm{Ni}_{2} \mathrm{~B}$ and $\mathrm{Ni}_{3} \mathrm{~B}$.

(3) The high-temperature microhardness of boronized $\mathrm{Ni}$ is higher than that of untreated Ni below about $800 \mathrm{~K}$.

(4) Friction properties and wear resistance to SUJ2 and SUS304 were improved by Ni boriding.
\end{abstract}

Key Words : Boriding, Nickel, Fluidized Bed, Friction High-temperature Microhardness

\section{1. 緒 言}

ニッケル $(\mathrm{Ni})$ は塩酸, 硫酸などの酸, 水酸化ナトリ ウムなどのアルカリおよび海水に対して優れた耐食性を 有している。そのため, $\mathrm{Ni}$ 合金は反応容器や貯蔵容器 などとして化学工業をはじめとする多くの分野で用いら れている。このように Niや Ni 合金は優れた耐食性を 有しているが，耐摩耗性においては必ずしも優れている とはいえない。

一般に, 耐摩耗性の向上には表面硬化法がよく知られ ている。鉄鋼の表面硬化法としては, 浸炭, 窒化, ホウ 化処理などが行われているが, Ni は浸炭や窒化処理で は表面硬化されない。一方, ホウ素(B)は多くの金属と ホウ化物を生成し ${ }^{1)}, \mathrm{Ni}$ とも容易にホウ化物を形成する ので Ni の表面硬化法としてホウ化処理は有効であると 考えられる。

ホウ化処理の方法としては, ホウ素の供給源が固体か らのパック法, ペースト法, 流動層法, 液体からの電解 法, 無電解法, さらに気体によるレトルト法などがある。 これらの処理方法の中でも流動層法は, (1) 基板表面と

*大阪府立産業技術総合研究所（广594-1157 大阪府和泉市 あゆみ野 2-7-1)

Technology Research Inst. of Osaka Pref. (7-1, Ayumino 2-chome, Izumi-shi, Osaka 594-1157)

**大阪府立大学 工学部（二599-8231 大阪府堺市学園町 1-1） College of Eng., Osaka Pref. Univ. (1-1, Gakuen-cho, Sakai-shi, Osaka 599-8231)
雲囲気との接触性が良いためホウ化速度が速い。(2) 物 質移動, 伝熱速度が大きく均熱性に優れている。(3) 低 ひずみ状態が確保される。(4) ホウ化処理後の付着物が 少なく, 表面が他の処理法に比べて滑らかである, とい う特幑を有している2)。

$\mathrm{Ni}$ のホウ化処理に関しては非晶質ボロンによるパッ ク法3)や三塩化ホウ素による気体法") が報告されている が,これらのホウ化剤はともに高価である上に，三塩化 ホウ素については毒性も強い。流動層を用いたホウ化処 理については上記の特徵から, 鉄鋼材料については研究

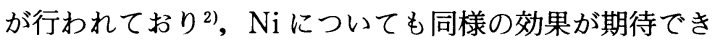
るが，ほとんど研究は行われていない。また，Niの木 ウ化層の組織や硬さ，また高温酸化についての報告5) は あるが，その摩擦・摩耗特性についてはほとんど知られ ていない。

そこで, 本研究では $\mathrm{Ni} に$ 流動層法を用いたホウ化処 理を試み, 処理後の表面層の解析を行うとともに, 生成 したホウ化層の高温硬さ, 摩擦・摩耗特性について検討 した。

\section{2. 実験方法}

\section{1 流動層ホウ化処理}

試料としては，市販の $\mathrm{Ni}$ 板（純度 $99.9 \%$ )を使用した。 試料の形状は $20 \times 50 \mathrm{~mm}$ ，厚み $3 \mathrm{~mm}$ で\# 240〜1200ま でのエメリー紙で研磨した後, ホウ化処理前にアセトン で脱脂, 洗净を行った。ホウ化処理は前報 ${ }^{6)}$ の流動層炉 
を用い，処理温度と処理時間をそれぞれ 1023〜1173 K， $1.8 \sim 14.4 \mathrm{ks}$ と変化させた。試料は流動層炉の上部から 吊し, ホウ化処理後, 空冷を行った。ホウ化㓮は, 主成

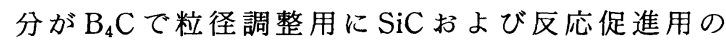
$\mathrm{KBF}_{4}$ が含まれている流動層用ホウ化剂を使用した。流 動ガスには窒素を用い, ホウ化剤の酸化防止のために一 部水素ガスを導入した。

$\mathrm{Ni}$ と鉄鋼材料の流動層におけるホウ化処理の反応の 違いについて調べるために，市販の S15C についても流 動層ホウ化処理を行った。試料の形状は $20 \times 30 \mathrm{~mm}$, 厚み $5 \mathrm{~mm}$ で\# 240〜1200 までのエメリー紙で研磨した 後, ホウ化処理前にアセトンで脱脂, 洗浄を行った。 $1223 \mathrm{~K}, 3.6 \mathrm{ks}$ でホウ化処理をし, 処理後空冷を行った。

また，ホウ化処理の反応について調べるために，パッ ク法を用いて検討を行った。パック法は $100 \phi \mathrm{mm}$, 高 さ $100 \mathrm{~mm}$ のステンレス容器に $\mathrm{SiC}$ (純度 $99.5 \%, 300$ メッシュ)粉体または, $10 \%$ の $\mathrm{KBF}_{4}$ 粉体を混合した $\mathrm{SiC}$ 粉体，それぞれ $300 \mathrm{~g}$ を入れ，その粉体中に試料の $\mathrm{Ni}$ 板を埋め込んで Ar 雾囲気中にて $1173 \mathrm{~K}, 7.2 \mathrm{ks}$ 保 持した。

\section{2 表面層の解析}

ホウ化処理後の表面層の解析には, X 線回折, 薄膜 $\mathrm{X}$ 線回折, EPMA, グロー放電発光分析 (GDS) を用い た。GDSは理学電機社製 System 3860 を使用し，ア ノード径 $4 \phi \mathrm{mm}, \operatorname{Ar}$ 流量 $200 \mathrm{cc} / \mathrm{min}$, 高周波周波数 $13.56 \mathrm{MHz}$ で $40 \mathrm{~W}$ の定電力により深さ方向の測定を 行った。薄膜 X 線回折は理学電機俐製 RINT 1500 にお いて薄膜アタッチメントを用いた。管球は $\mathrm{Cu}$ で管電圧 $40 \mathrm{kV}$, 管電流 $150 \mathrm{~mA}$, モノクロメーターを使用し, X 線入射角度 $\alpha$ を 0.5 度から 5 度に変化させ, 回折角度 $2 \theta$ を 20 度から 90 度までについて測定を行った。

\section{3 高温硬さ}

高温硬さ測定は試料表面から保ニコン製, 高温マイク ロビッカース硬度計 $\mathrm{QM}-2$ 型を使用して行った。測定 条件は荷重 $0.49 \mathrm{~N}$, 昇温速度 $20 \mathrm{~K} / \mathrm{min}$, 真空雾囲気と した。

\section{4 摩擦・摩耗試験}

摩擦・摩耗特性の評価には, 往復しゅう動式の Pinon-Flat 型摩擦・摩耗試験機》)を用いた。試料台に取付 けた平板試料(Flat) と摩擦相手材 (Pin) の往復摩擦を行 わせる。そのときの試料と摩擦相手材の間に働く摩擦力 を検出し, 摩擦係数を算出した。摩擦相手材としては, 摩擦・摩耗試験によく使用される軸受鋼(SUJ 2) 球と, SUS 304 球を使用した。なお, 球の直径は $4.8 \mathrm{~mm}$ であ る。試料はアセトンで超音波洗浄した後, 試験に供した。 試験は荷重: $1.96 \mathrm{~N}$, 摩擦速度: $20 \mathrm{~mm} / \mathrm{s}$, 摩擦ス卜

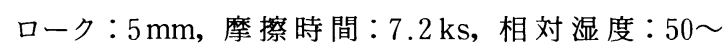
$60 \%$, 室温, 大気中の条件で行った。

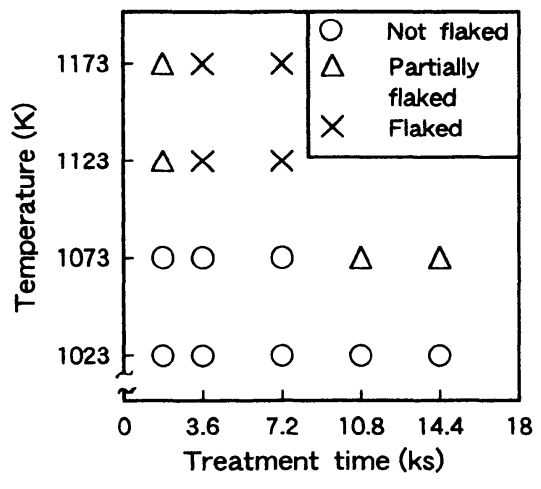

Fig. 1 Surface conditions of $\mathrm{Ni}$ boronized in fluidized bed at various temperatures and times.

摩耗特性は, 摩擦試験後の摩耗痕の断面形状を表面粗 さ計で測定することによって求めた。また，相手材の摩 耗は試験後の摩擦面について SEM 観察を行い, その大 きさを未処理材との比較で評価した。

\section{3. 実験結果および考察}

\section{1 表面状態および組織}

流動層による Ni のホウ化処理では, 処理温度が高い 場合, 鉄鋼材料ではみられなかった ${ }^{2)}$ 生成層のはく離が 観察された。このような生成層のはく離は, 非晶質ボロ

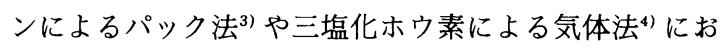
いては報告されていない。図1にホウ化処理における温 度と時間を変化させた場合のホウ化処理後の試料の表面 状態を示す。生成層は, 全くはく離の認められない試料, 生成層の一部が膨れ上がりはく離がみられる試料, 生成 層を手で触れると全面的にシート状に簡単にはく離する 試料の 3 つのグループに分けることができた。図 1 から 明らかなようにホウ化処理温度が高いほど, また処理時 間が長いほどはく離が進む傾向が認められたが, $1073 \mathrm{~K}$ で処理時間が $7.2 \mathrm{ks}$ までの木ウ化処理条件では，はく 離を起こさずホウ化層を得ることができるのがわかる。

図 2 にホウ化処理条件とホウ化層の厚みの関係を示す。 ホウ化層の厚みは断面組織より求めた。1023Kではホ ウ化層の厚みは処理時間が長くなるにつれて徐々に厚く

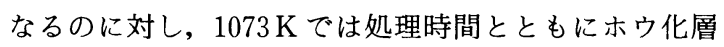
が急激に厚くなり, ホウ化が進んでいる。その厚みは $1073 \mathrm{~K}, 7.2 \mathrm{ks}$ の処理条件において約 $25 \mu \mathrm{m}$ の値が得 られた。それ以上処理時間が長くなると厚みは厚くなる が, はく離が認められた。Ni はホウ化処理において, $\mathrm{Fe}$ などの他の金属と比較して, ホウ化速度が速く, 厚 い木ウ化層が得られることが知られている31,4)。しかし， 流動層によるホウ化処理では処理温度が高いと生成層の はく離が起こり，厚い $\mathrm{Ni}$ のホウ化層を得ることができ 


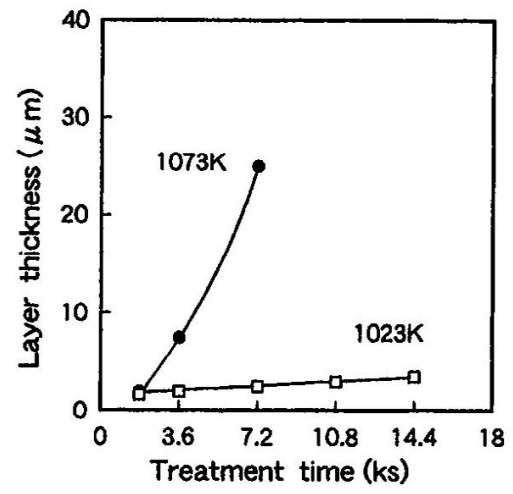

Fig. 2 Relation between treatment time and layer thickness.

なかった。

図 3 にホウ化処理後の断面組織の一例として, (a) $1073 \mathrm{~K}$ ，(b) $1173 \mathrm{~K} て 7.2 \mathrm{ks}$ 処理した場合を示す。ホウ 化処理温度 $1073 \mathrm{~K}$ ，(a)では，ホウ化層の母材との境界 はほほ平滑で，炭素鋼や低合金鋼に認められるくし歯 状8)とは著しく異なっている。ホウ化層中には所久ボイ ドがみられ，ホウ化䫡に続く拡散層や，粒界層は認めら れなかった。一方，木ウ化処理温度 $1173 \mathrm{~K}$ ては生成矦 は全面的にはく離し，わずかに残った部分 (b)では，(a) の組織とはかなり異なっている。すなわち，ホウ化層の 中には黒い大きな組織がみられ，また母材との境界近く にも多くの小さな粒状の組織が集まっているのが観察さ れ，その付近からはく離が生じた。

\section{2 表面分析}

図 4 はホウ化処理温度 $1073 \mathrm{~K}$ で $7.2 \mathrm{ks}$ 処理したホウ 化層の GDSによる深さ方向における $\mathrm{B} ， \mathrm{Si} ， \mathrm{Ni}$ の濃度 分布を示す。構成元素のスパッタリング速度に依存する が, 横軸のスパッタリング時間が表面からの深さに対応 する。まず，Bに注目すると，ホウ化層中での B の濃 度の違いが明確に観測された。すなわち，B 濃度は最表 面において，わずかに濃度が低いがその後，一定值に達 した後, 濃度はほほ段階的に滅少し母材にかけて急激に 低下した。最表面において B 濃度がわずかに低いのは， 後述するように，Bのかわりに Si が含まれるためと考 えられる。次にNiについて見ると，深さ方向に対して 增加し，母材に至る分布を示した。また，BやNi のほ かに最表面において Si が認められた。試料には Si は含 まれていないので，この Si はホウ化戍からのものと考 えられる。

GDS では試料を数百 $\mathrm{Pa}$ の真空度で吸引しながらう ンプに付着させて測定を行うため,はく離した試料の生 成層の深さ方向の濃度分布をみることはできない。そこ で, EPMAではく離が生じなかった試料と生じた試料

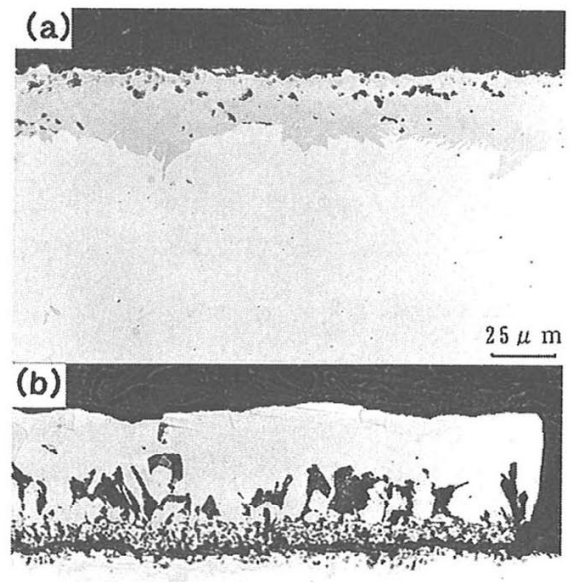

$25 \mu \mathrm{m}$

Fig. 3 Cross section of surface layers

(a) $1073 \mathrm{~K}, 7.2 \mathrm{ks}$ (b) $1173 \mathrm{~K}, 7.2 \mathrm{ks}$ (as polished)

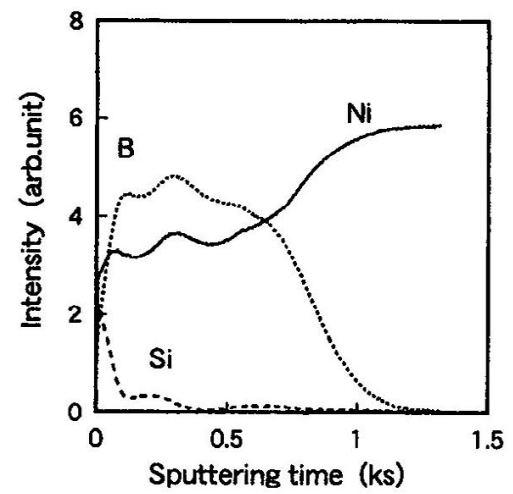

Fig. 4 In-depth analysis of boronized $\mathrm{Ni}$ by GDS. $(1073 \mathrm{~K}, 7.2 \mathrm{ks})$

について元素の分布を調べ比較を行った。ホウ化処理温 度 $1073 \mathrm{~K}$ の結果を図 5 ，ホウ化処理温度 $1173 \mathrm{~K}$ の結果 を図 6 にそれぞれ示す，処理時間はいずれも $7.2 \mathrm{ks}$

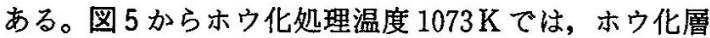
は主に Ni とBのホウ化物からなっていることがわかる。 また, EPMA からも GDS と同様に表面層の Si を検出 することができた。一方，図 6 のホウ化処理温度 1173 $\mathrm{K}$ の試料では生成層は主に Ni と $\mathrm{Si}$ からなっており，B はほとんど検出されなかった。このことは，ホウ化処理 温度が $1073 \mathrm{~K}$ では通常のホウ化が主に進んだのに対し，

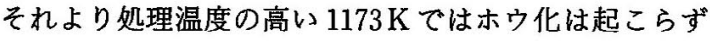
シリコン化が生じていることを示している。したがって, 非晶質ボロンによるパック法や三塩化ホウ素による気体 


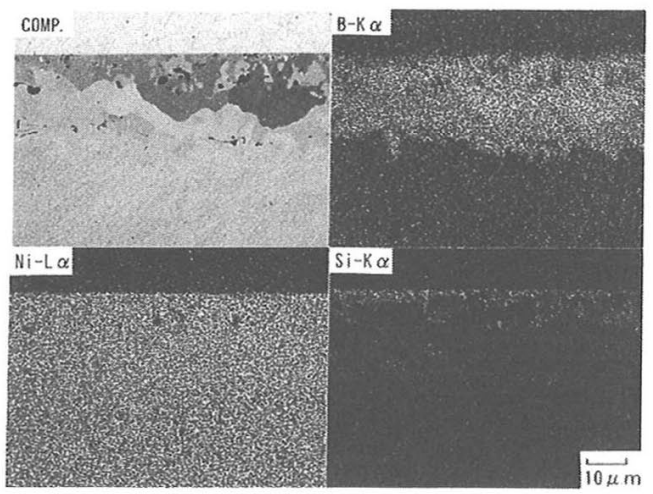

Fig. 5 Back-scattered electron image and X-ray images of the boride layer $(1073 \mathrm{~K}, 7.2 \mathrm{ks})$ by EPMA.

法のホウ化処理では生成層のはく離が生じず, 流動層木 ウ化処理で生成層のはく離が生じるのは, 上述のシリコ ン化によるものと考えられる。これ以外にも生成層のは く離に影響する要因としてホウ化処理後の冷却速度が考 えられるが, 空冷よりも冷却速度が遅い炉中冷却を行っ た場合も, 処理温度が高い場合には生成層のはく離が認 められた。したがって, 生成層のはく離には, シリコン 化により母材との境界に生成した小さい粒形でボイド状 の組織が影響していると考察される。

このようなシリコン化は, 試料の NikはSi は含ま れていないのでホウ化剤に粒径調整用として含まれてい る $\mathrm{SiC}$ と $\mathrm{Ni}$ の反応によって生じたと考えざるを得ない。 そこで，シリコン化の原因を詳しく検討するためにパッ ク法を用いて Ni と SiCの反応について調べた。その結 果, 粉体が $\mathrm{SiC}$ のみの場合, $\mathrm{Ni}$ は $\mathrm{Si}$ と反応しなかった。 しかし，ホウ化剤に反応促進用として含まれる $\mathrm{KBF}_{4}$ を $\mathrm{SiC} に 10 \%$ 添加し, 同様な処理を行った場合, 厚み が約 $75 \mu \mathrm{m}$ の生成層が認められた。また,この試料の 一部においてはく離も観察された。この試料の GDSに よる強度一時間のプロファイルを測定した結果, 層中に Siが取り込まれ，シリコン化が起きていることがわ かった。すなわち, $\mathrm{SiC} と \mathrm{KBF}_{4}$ が存在すると $\mathrm{SiC}$ が $\mathrm{Ni}$ と反応し, Ni のシリコン化が生じることになる。

現在, 流動層用木ウ化肪は 1 種類しかなくその成分は 公表されていないが，主成分は $\mathrm{B}_{4} \mathrm{C} て ゙$ 粒径調整剤に $\mathrm{SiC}$, 反応促進剂に $\mathrm{KBF}_{4}$ を含んでいる。ホウ化剂が流 動層で流動するように，粒径調整郕を用いて粒径 220〜 $350 \mu \mathrm{m}$ に造粒されている。粒径調整郕には，ホウ紊は 高温で活性化されると酸素との親和性が高い9 ので, 酸 化物を用いることはできない。また，流動ガスの軽減か ら充填密度が小さいことが要求される。この場合, $\mathrm{SiC}$ の充填密度は $0.95 \mathrm{~g} / \mathrm{cm}^{3}$ でアルミナ粒子の充嫃密度 $1.8 \mathrm{~g} / \mathrm{cm}^{3}$ と比べると小さい。以上の理由から $\mathrm{SiC}$ が粒

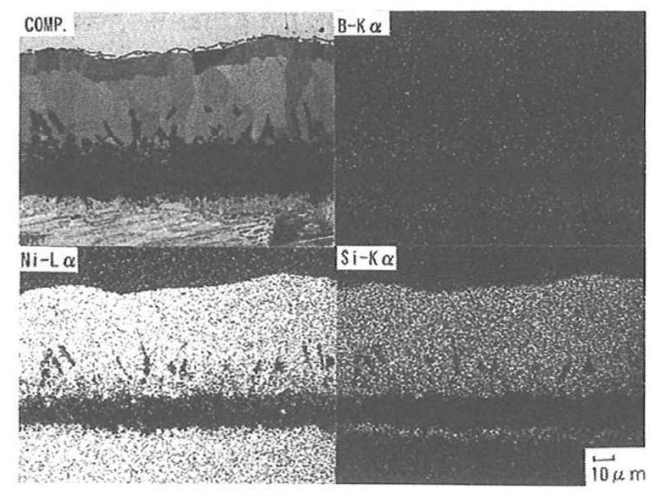

Fig. 6 Back-scattered electron image and X-ray images of the boride layer $(1173 \mathrm{~K}, 7.2 \mathrm{ks})$ by EPMA.

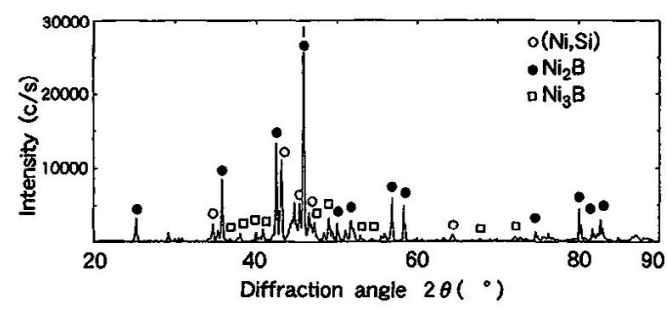

Fig. 7 X-ray diffraction patterns of boronized $\mathrm{Ni}$. (1073 K, $7.2 \mathrm{ks})$

径調整片として用いられており，粒径調整剤なしではホ ウ化剤を流動させることは難しい。流動層では, 反応促 進剤によって粒状ホウ化剤を覆うように反応ガス境膜が 生成し, この境界膜がスと試料とが反応し, 木ウ化が起

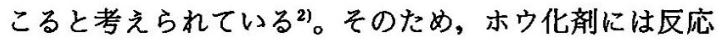
促進剈が必要である。このように流動層ホウ化処理では, ホウ化剤には $\mathrm{SiC}$ の他に反応促進用の $\mathrm{KBF}_{4}$ が含まれ ていることから，パック法での実験と同様な反応が流動 層用ホウ伦剤を用いた場合も起こり, Niのシリコン化 が生じたものと考えられる。

一方，鉄鋼材料においては，同じ流動層によるホウ化 処理でも，このようなシリコン化は報告されていない2》。 流動層でホウ化処理した S $15 \mathrm{C}$ の GDSによる強度一時 間のプロファイルを測定した結果, S 15Cでは, Niの 場合と異なり, シリコン化はみられなかった。

ハステロイ B などの $\mathrm{Ni}$ 含有量の多い合金をパック法 で $\mathrm{SiC}$ や応促進剤を含んだホウ化剤を用いて処理し た場合, 次のような反応が進み, シリコン化が起こるこ とが報告されている10。

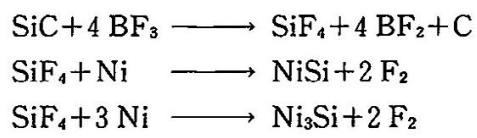




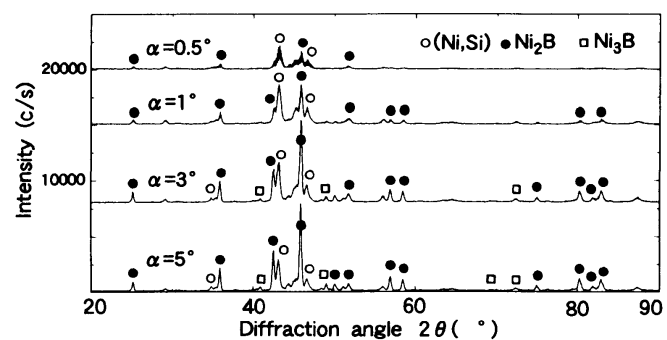

Fig. 8 Glancing incidence X-ray diffraction patterns of boronized $\mathrm{Ni}$.

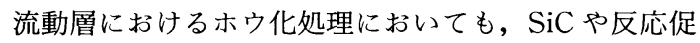
進剤として $\mathrm{KBF}_{4}$ を含んだホウ化剂を用いた場合，同 様な反応によって Ni のシリコン化が起きると考えられ る。一方, $\mathrm{Ni}$ と Fer゙シリコン化に差が生じたのは, $\mathrm{Fe}$ の場合は上記の反応が起こらず，ホウ化が優先的に 生じるためと推測される。

そこで, 本実験でははく離が生じず, 層の厚みが最も 厚くなる処理温度 $1073 \mathrm{~K}$, 処理時間 $7.2 \mathrm{ks}$ の試料を中 心にホウ化層の特性を調べた。この条件でホウ化処理し た試料の X 線回折図形を図 7 に示す。ホウ化層は主に $\mathrm{Ni}_{2} \mathrm{~B}, \mathrm{Ni}_{3} \mathrm{~B}$ からなっている。印のピークについては 同定は困難であったが，GDS や EPMA の結果から $\mathrm{Ni,}$ Si の化合物と考えられる。

$\mathrm{X}$ 線回折で確認できた, ホウ化層中の化合物の分布 を調べるために薄膜 X 線回折により X 線入射角度を変 化させて測定を行った。この場合, 入射角度が低いほど $\mathrm{X}$ 線の侵入深さが浅くなり,より表面層の構造解析を 行うことができ, X 線侵入深さは $\alpha=0.5^{\circ}$ で約 $0.6 \mu \mathrm{m}$, $5^{\circ}$ で約 $5.5 \mu \mathrm{m}$ となる。ホウ化処理温度 $1073 \mathrm{~K}$, 処理温 度 $7.2 \mathrm{ks}$ でホウ化処理した試料の薄膜 X 線回折図形を 図 8 に示す。X 線入射角度 $\alpha$ が小さい時は $\mathrm{Ni}, \mathrm{Si}$ の化 合物がみられ, 次に $\alpha$ が大きくなるにつれて $\mathrm{Ni}_{2} \mathrm{~B}$ の ピーク強度が増し,さらに $\alpha$ が大きくなると $\mathrm{Ni}_{3} \mathrm{~B}$ の ピークがみられることにより, 最表面が $\mathrm{Ni}, \mathrm{Si}$ の化合 物, 次の層が $\mathrm{Ni}_{2} \mathrm{~B}$, さらに次の層が $\mathrm{Ni}_{3} \mathrm{~B}$ と考えられ る。またこのことは GDS の強度一時間のプロファイル やEPMAの結果とも一致している。

\section{3 断面硬さおよび高温硬さ}

図 9 はホウ化層の断面硬さ分布をヌープ硬さ計の荷重 $0.098 \mathrm{~N}$ で測定した結果を示す。ホウ化層部の硬さは約 $1300 \mathrm{HK}$ の值を示し，その後硬さは約 $25 \mu \mathrm{m}$ のところ で急激に低下し, 母材硬さに至る。この硬さの急激に低 下する表面からの距離は, 組織にみられるホウ化層の厚 さと良い一致を示した。

流動層ホウ化処理の $1073 \mathrm{~K}, 7.2 \mathrm{ks}$ でのホウ化層の

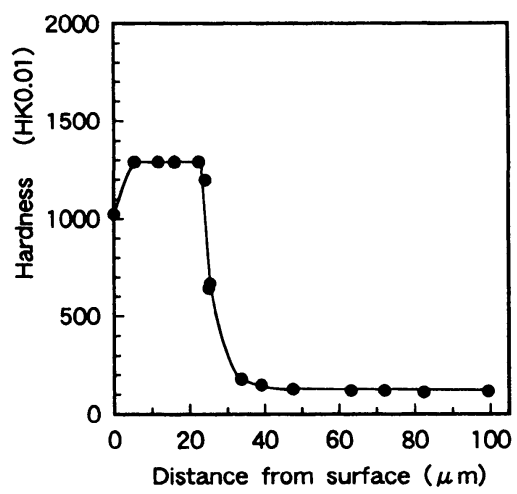

Fig. 9 Knoop hardness distribution from the surface of boronized $\mathrm{Ni}$.

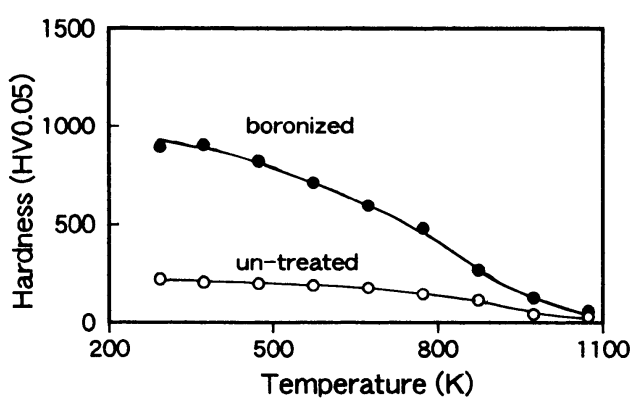

Fig. 10 High-temperature microhardness of boronized Ni.

厚みは約 $25 \mu \mathrm{m}$ で, 同じ処理温度でさらに処理時間の 長い $21.6 \mathrm{ks}$ の反応条件における，非晶質ボロンを用い たパック法3)のホウ化層の厚み約 $10 \mu \mathrm{m}$ より厚く,ま た硬さ值も約 $1100 \mathrm{HV}$ が得られ, パック法の約 $200 \mathrm{HV}$ より，かなり高い值を示している。これは，基板表面と 雾囲気との接触性が良いためホウ化速度が速い流動層の 特徵と考えられる。

ホウ化層最表面の硬さは試料表面から測定した場合, 約 $1000 \mathrm{HK}$ とホウ化層内部に比べると硬さ值が低く なっている。 $\mathrm{NiSi} や \mathrm{Ni}_{3} \mathrm{Si}$ の硬さ值は約 $400 \mathrm{HV}$ であ ることが報告されている11)。したがって，最表面部の硬 さ值がホウ化層内部に比べて低くなっているのは, 前述 したように，ホウ化肪に含まれる $\mathrm{Si}$ が最表面に侵入し， $\mathrm{Ni}, \mathrm{Si}$ の化合物層が生成したためと考えられる。

一般に，ホウ化処理は鋼の耐摩耗性や耐食性などの他 に高温硬さ特性を向上させることが知られている3゙。し かし，木ウ化処理した $\mathrm{Ni}$ の高温硬さ特性については報 告されていない。そこで, 流動層でホウ化処理した $\mathrm{Ni}$ の真空雾囲気での高温硬さ特性を測定した。ホウ化層の 高温硬さを測定した結果を図 10 に示す。Ni のホウ化層 は加熱温度の上昇につれて硬さ值は低下するが, 約 800 


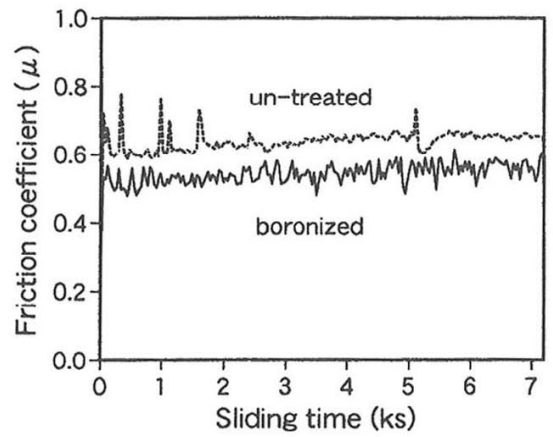

Fig. 11 Variation of the friction coefficient of the specimen slid against SUJ 2 with sliding time.

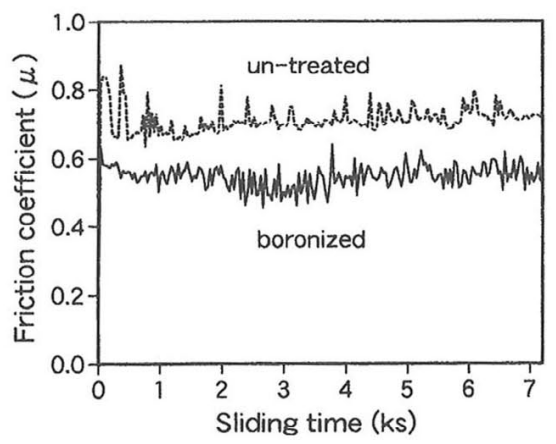

Fig. 12 Variation of the friction coefficient of the specimen slid against SUS 304 with sliding time.

Kにおいても約 $500 \mathrm{HV}$ の硬さ值を有しており，ホウ化 処理により $\mathrm{Ni}$ の高温硬さ特性の向上がみられた。

\section{4 摩擦・摩耗特性}

図 11，12に SUJ 2, SUS 304 を相手材とした場合の 未処理材およびホウ化処理材に対する摩擦係数の時間変 化をそれぞれ示す。相手材がSUJ 2 の場合, 未処理材 とホウ化処理材では摩擦係数は未処理材が 0.66 なのに 対してホウ化処理材では 0.55 となりホウ化処理により 摩擦係数の低減がみられた。また，相手材が SUS 304 の場合も同様に摩擦係数は未処理材が 0.73 なのに対し， ホウ化処理材は 0.56 となりホウ化処理により摩擦係数 の低減が認められた。

図 13 に，それぞれ相手材をSUJ 2, SUS 304 とした 場合の摩擦試験後における摩耗痕の断面形状の比較を示 す。相手材がSUJ 2 の場合, 摩耗痕の深さは未処理材 では約 $8 \mu \mathrm{m}$, ホウ化処理材では約 $14 \mu \mathrm{m}$ であり中心部 での深さはホウ化処理材の方が深いが, 周辺部ではホウ 化処理材の方が摩耗痕の深さは浅い。比摩耗量は未処理 材で約 $1.0 \times 10^{-7} \mathrm{~mm}^{3} / \mathrm{N} \cdot \mathrm{mm}$, 木ウ化処理材は約 $8.3 \times 10^{-8} \mathrm{~mm}^{3} / \mathrm{N} \cdot \mathrm{mm}$ であった。また, 相手材が

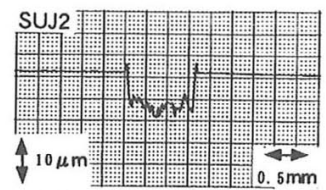

(a) Un-treated specimen

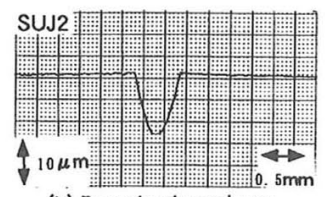

(b) Boronized specimen

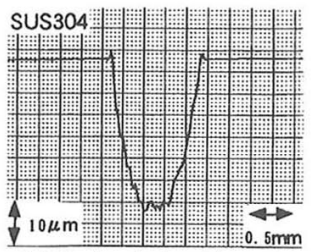

(a) Un-treated specimen

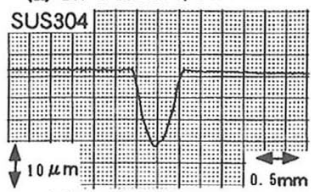

(b) Boronized specimen

Fig. 13 Surface profiles of the wear scars on the flat specimens slid against SUJ 2 and SUS 304.

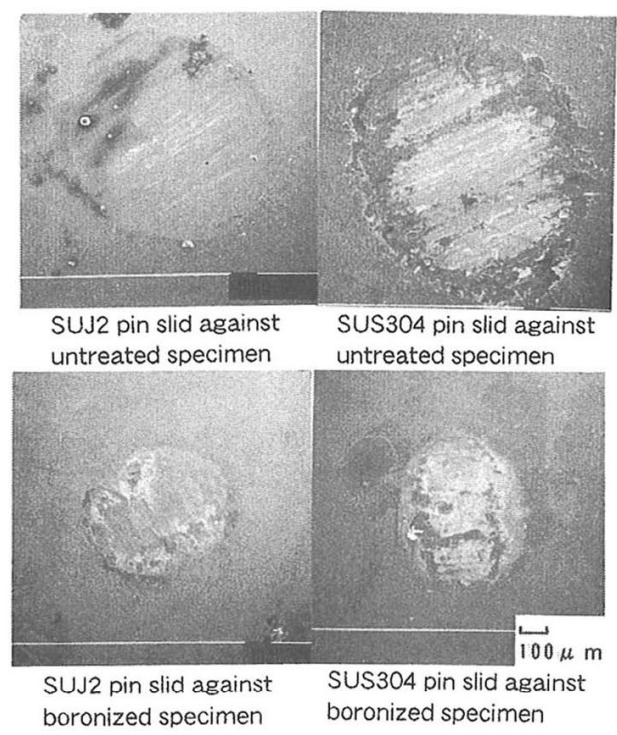

Fig. 14 SEM micrographs of the surface of pin.

SUS 304 の場合, 摩耗痕の深さは未処理材では約 34 $\mu \mathrm{m}$, ホウ化処理材では約 $17 \mu \mathrm{m}$ であり, 比摩耗量は末 処理材で約 $4.6 \times 10^{-7} \mathrm{~mm}^{3} / \mathrm{N} \cdot \mathrm{mm}$ ，木ウ化処理材は約 $1.1 \times 10^{-7} \mathrm{~mm}^{3} / \mathrm{N} \cdot \mathrm{mm}$ となり，いずれの相手材に対し てもホウ化処理材の比摩耗量が未処理材より減少し, 耐 摩耗性の向上が認められた。

摩擦試験後における相手材 SUJ 2, SUS 304 の摩擦痕 の SEM 観察結果を図 14 に示す。図から明らかなよう に, 摩擦痕の大きさはホウ化処理材に対する方が未処理 材に比較して，小さく観察されている。すなわち，ホウ 化処理材では, 未処理材より相手材の摩耗量が減少して おり, ホウ化処理は相手材の摩耗量の低隇にも効果を有 することが確認できた。 


\section{4. 結言}

本研究の結果をまとめると以下のようになる。

(1) 流動層による Ni のホウ化処理において, 処理温度 が高い場合や，処理時間が長い場合には，生成層のはく 離が認められ良好な生成層は得られなかった。その場合 には，ホウ化よりもシリコン化が生じていた。したがっ て，はく離にはシリコン化が関与しており，そのシリコ ン化は流動層用ホウ化牏に含まれている $\mathrm{SiC}$ と $\mathrm{KBF}_{4}$ の共存下における $\mathrm{SiC}$ と $\mathrm{Ni}$ の反応によるものと考えら れた。

（2）生成層のはく離が生ぜず，ホウ化が主であるホウ化 処理条件の $1073 \mathrm{~K}, 7.2 \mathrm{ks}$ で約 $25 \mu \mathrm{m}$ のホウ化層が得 られた。このホウ化層は $1300 \mathrm{HK}$ の硬さを示し, 主に $\mathrm{Ni}_{2} \mathrm{~B}, \mathrm{Ni}_{3} \mathrm{~B}$ から構成されていることが確認できた。

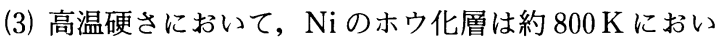
ても約 $500 \mathrm{HV}$ の硬さ值を有し，未処理材と比較して大 きな硬さ值を保っており，ホウ化処理により $\mathrm{Ni}$ の高温 硬さ特性の向上が認められた。

(4) 本実験条件において，ホウ化処理材の摩擦係数は SUJ 2，SUS 304 を相手材に用いた場合，ともに未処理 材より低い值を示した。また，耐摩耗性についても，比 摩耗量が未処理材より減少し,さらに, 相手材の摩擦痕 の大きさも小さくなることが認められた。したがって， ホウ化処理は $\mathrm{Ni}$ の摩擦係数の低隇や耐摩耗性の向上, さらに相手材に対する攻撃性の低隇に有効であることが 確認できた。
最後に，摩擦・摩耗試験に関して貴重な御助言をいた だいた当産業技術総合研究所の出水敬主任研究員, 高温 硬さ測定に協力していただいた同研究所の足立振一郎研 究員ならびに資料を提供していただいたワッカーケミカ ルズイーストアジア(株)に対し樑く感謝いたします。

(Received August 17, 1998 ; Accepted December 14, 1998)

\section{文献}

1) F. Matsuda, K. Nakata, K. Tohmoto ; Trans. JWRI, 13, $123(1984)$

2 ）池永 明；金属, 11, 12 (1990)

3 ) F. Matsuda, K. Nakata, Y. Nishio ; Trans. JWRI, 16, 145 (1987)

4 ）片桐敏夫, 藤井京子, 高木信次郎 ; 日本金属学会誌，31，904 (1967)

5 ）千葉和茂, 片桐敏夫, 藤井京子, 嵯峨卓郎；熱処理，31，273 (1991)

6 ）上田順弘, 佐藤幸弘, 浦谷文博, 曾根 匠, 池永 明, 川本 信；表面技術, 48, 343 (1997)

7 ）出水 敬, 曽根 匠, 夏川一輝, 藤島征雄；材料，42, 997 (1993)

8 ）池永 明, 川本 信, 兽根 匠, 福田 達；鋳物，63，437 (1991)

9 ）ワッカーケミカルズイーストアジア揦 資料 BORONIZING IN A FLUIDIZED BED, 3 (1986)

10) H. J. Hunger, G. Trute ; Mater. Sci. Forum, 163-165, 341 (1994)

11) Г. В. Самсонов, И. М. Виницкий; Тугоплавкие соединения: Справочник, 500с (Москва, Металлургия, 1976) 